\title{
Metoidioplasty as a one-stage phallic reconstruction in transmen
}

\author{
Marta Bizic ${ }^{1,2}$, Borko Stojanovic ${ }^{1,2}$, Marko Bencic ${ }^{2}$, Noemi Bordas ${ }^{2,3}$, Miroslav Djordjevic ${ }^{1,2}$ \\ 1Department of Urology, Faculty of Medicine, University of Belgrade, Belgrade 11000, Serbia. \\ ${ }^{2}$ Belgrade Center for Urogenital reconstructive Surgery, Belgrade 11000, Serbia. \\ ${ }^{3}$ Department of Urology, Kiskunhalasi Semmelweis Kórház, Kiskunhalas 6400, Hungary.
}

Correspondence to: Dr. Marta Bizic, Department of Urology, Faculty of Medicine, University of Belgrade, Tirsova 10, Belgrade 11000, Serbia. E-mail: martabizic@uromiros.com

How to cite this article: Bizic M, Stojanovic B, Bencic M, Bordas N, Djordjevic M. Metoidioplasty as a one-stage phallic reconstruction in transmen. Plast Aesthet Res 2020;7:43. http://dx.doi.org/10.20517/2347-9264.2020.80.

\begin{abstract}
Received: 17 Apr 2020 First Decision: 18 May 2020 Revised: 7 Jun 2020 Accepted: 19 Jun 2020 Published: 15 Aug 2020
Academic Editors: Marlon E. Buncamper, Stan J. Monstrey Copy Editor: Cai-Hong Wang Production Editor: Jing Yu
\end{abstract}

\begin{abstract}
Gender dysphoria is a condition where there is a discrepancy between the gender assigned at birth and the desired gender, leading the patient to pursue surgical intervention. Reconstruction of the neophallus for transmen is still challenging, even though there are many surgical techniques with satisfying results. The aim of neophallic reconstruction in gender affirmation surgery (GAS) for transmen is to provide stand-up voiding, erotic sensation, orgasm and penetration ability, and acceptable donor site morbidity with minimal scarring and complications. Metoidioplasty as a variant of phalloplasty for transmen is a one-stage procedure that results in male-like external genitals, with minimal scarring, ability of standing micturition, and full erogenous sensation with the ability to achieve orgasm during sexual intercourse. Metoidioplasty is a method of choice for those transmen who wish to have GAS in one procedure without multi-staged procedures to create the adult-male-sized neophallus.
\end{abstract}

Keywords: Clitoris, gender affirmation surgery, metoidioplasty, neophallus, genital reconstruction, transmen

\section{INTRODUCTION}

Gender affirmation surgeries usually represent the final step in the transition process of an individual suffering from gender dysphoria. Genital reconstructive surgeries, known as "bottom surgeries", are performed according to Standards of Care (SOC) of the World Professional Association for Transgender Health (WPATH): they require two letters of recommendation by two board certified mental health

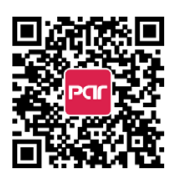


professionals and must come after at least 12 months of substitution hormonal therapy ${ }^{[1]}$. Preoperative consultation with the selected surgeon performing gender affirmation surgery (GAS) is welcome in order to reconcile the patients' expectations of surgery outcomes and the possibilities of modern medicine, to prevent any postoperative disappointmen ${ }^{[2]}$. Even though under testosterone therapy transmen's body encounters a lot of changes, some individuals still require facial and body masculinization procedures or frontline hair procedures.

It is still difficult to assess the real prevalence of gender dysphoria, but the latest studies report an increase in prevalence for individuals assigned male at birth to 0.014-0.015, while, for individuals assigned female at birth, it is 0.002-0.003. The self-report of transgender identity in children, adolescents, and adults, ranging from $0.5 \%$ to $1.3 \%$, has also increased according to recent studies ${ }^{[3,4]}$.

Phalloplasty, as previously said, is still a challenging procedure, reserved for highly specialized institutions and surgeons. The first phalloplasty was performed in the 1930s by Bogoras, followed by years of refining surgical techniques to satisfy patients' expectations of functionality and esthetics. However, there is no replacement for erectile, urethral tissue, and nerves that would provide ideal male genitals for males requiring genital reconstruction ${ }^{[5,6]}$. The reconstruction of the neophallus should be performed as a onestage procedure, yielding sensation (tactile and erogenous), functional neourethra (ability of stand-up voiding), penetrative sexual intercourse, and minimal scarring of the donor site ${ }^{[5,7]}$. Unfortunately, to this day, there is no single surgical technique to satisfy all these goals of male genitalia reconstruction ${ }^{[8]}$.

Male genitalia reconstruction in transmale individuals can be performed by two surgical approaches: phalloplasty and metoidioplasty (a variant of phalloplasty). Phalloplasty involves the creation of an adultsized neophallus using local or outlying tissue flaps, as either pedicled or free flaps with microvascular anastomosis. Rigidity for penetration during sexual intercourse is obtained after penile prosthesis implantation. Metoidioplasty involves creation of the neophallus using the hormonally-hypertophied clitoris, with or without urethroplasty, and scrotoplasty, with or without testicular prostheses implantation. In the majority of patients, metoidioplasty enables voiding in standing position and full erogenous sensation, but penetration during sexual intercourse is possible in only rare cases (by self-report) ${ }^{[5,9]}$.

The first report of using clitoris in male genitalia reconstruction was in 1973, and as a term "metoidioplasty" was first introduced by Lebovic and Laub, originally from the Greek words "meta" (change), "aidion" (female genitalia), and "plasty" (formation) ${ }^{[10,11]}$. Metoidioplasty can be considered as the method of choice, for those individuals requiring male genitalia reconstruction in single surgery to complete their transition and who do not wish to have stigma scars outside the genital area.

This narrative review aims to evaluate all available techniques of metoidioplasty and to report the postoperative results and complications. The paper was approved by the Institutional Review Board (No. 2-1-1/2020).

\section{Preoperative evaluation}

Transmale individuals undergoing genital reconstruction in GAS are required to have spent at least one year on hormonal substitution therapy according to the WPATH SOC ${ }^{[1]}$. For those who have chosen metoidioplsty as the surgical technique, additional preoperative short-term use of vacuum pump in combination with local application of dihydrotestosterone gel is recommended to provide better postoperative results ${ }^{[5,12]}$.

Knowledge of female and male anatomy and embriology is of essential importance for surgeons performing transgender genital reconstructive surgeries. Female and male external genitals, i.e., the clitoris and penis, 
are homologous organs and are both responsible for sexual pleasure ${ }^{[13]}$. The clitoris, similarly to the penis, has a glans, prepuce, two corpora cavernosa, crura, bulbs, suspensory ligaments, and root. Unlike the penis, it does not contain corpus spongiosum with urethra. In cis-females, clitoral glans and prepuce are the only visible parts of the clitoris, while the clitoral body is curved, hidden, and attached with two parts of suspensory ligament (superficial and deep) to the pubic bones and fatty tissue of the mons, preventing its protrusion during arousal ${ }^{[14]}$. Due to the presence of androgen receptors, the clitoris enlarges under testosterone therapy, so that one part of the clitoral body becomes visible as well. As reported by several different studies, the preoperative clitoral size in transmen varies from 2.5 to $4.6 \mathrm{~cm}^{[5,15,16]}$. Its dissection and the division of suspensory ligaments during metoidioplasty will allow for straightening and additional lengthening of the clitoris and enable voiding while standing. The labia minora are paired, hairless mucocutaneous structures, rich in nerve endings and sensory receptors with very good vascularization, which makes them good tissue for genital reconstruction. The labia majora are paired fibroadipose structures homologous to the scrotum in cis-males and are used for scrotum reconstruction in transmen $\mathrm{GAS}^{[5,17]}$.

Even though GASs have been performed for more than 50 years, little is known about their effects on the sexual experiences of transpeople, especially of transmen. Preoperative counseling with a sexologist, the treating surgeon, and a psychotherapist is very important to reveal the patient's sexuality and sexual functioning before the surgery, but will also be of essential importance after the $\mathrm{GA}^{[18]}$.

\section{Operative techniques}

From the time it was first introduced as a genital reconstruction procedure using hypertrophied clitoris, metoidioplasty has been refined by several authors in order to gain neophallic length, achieve more naturallooking male-like genitalia, and to provide voiding while standing ${ }^{[10,19]}$. Lebovic and Laub performed ventral chordee release with urethral reconstruction in two stages, wherein the patient was not able to void while standing after the first stage ${ }^{[10,20]}$. Bouman's refinement consisted of urethral lengthening to the tip of the clitoris using the vaginal mucosal flap, but without ventral chordee release ${ }^{[10,21]}$. Gilbert's modification of the technique included clitoral release and complete urethral reconstruction using only local flaps originating from the labia minora ${ }^{[10,22]}$. Hage et al. ${ }^{[7]}$ used the combination of the abovementioned techniques (Bouman's and Laub's) to obtain the best possible results for their patients, who set standing micturition as their main goal $^{[7,10]}$. Later, Hage and van Turnhout ${ }^{[23]}$, in their long-term follow-up study, reported that, on average, 2.6 procedures were needed to achieve satisfying results after performed metoidioplasty. For the purpose of continuous improvement of surgical techniques, Perovic and Djordjevic ${ }^{[24]}$ reported very high success rate in their series of patients who underwent metoidioplasty related to standing micturition and esthetic appearance.

Nowadays, there are three major subtypes of metoidioplasty that can be considered as distinct procedures: simple metoidioplasty, ring metoidioplasty, and complete metoidioplasty (Belgrade metoidioplasty).

Simple metoidioplasty involves the release of clitoral ligaments and urethral plate, but without urethral reconstruction. It is usually selected by the patients who fear postoperative complications related to urethroplasty. It results in male-like genitals, with a sensate small phallus, scrotum with or without testicular implants, and native urethral opening without the possibility of voiding while standing. The complication rate with simple metoidioplasty is rather small and acceptable by the patients and their surgeons (less than 5\%) and is usually related to the skin (dehiscence, local infection, and rotation of the neophallus) ${ }^{[25,26]}$.

Ring metoidioplasty includes urethral reconstruction along with the dissection of the suspensory ligaments of the clitoris and ventral urethral plate division. The urethral ring flap is harvested from the vaginal 


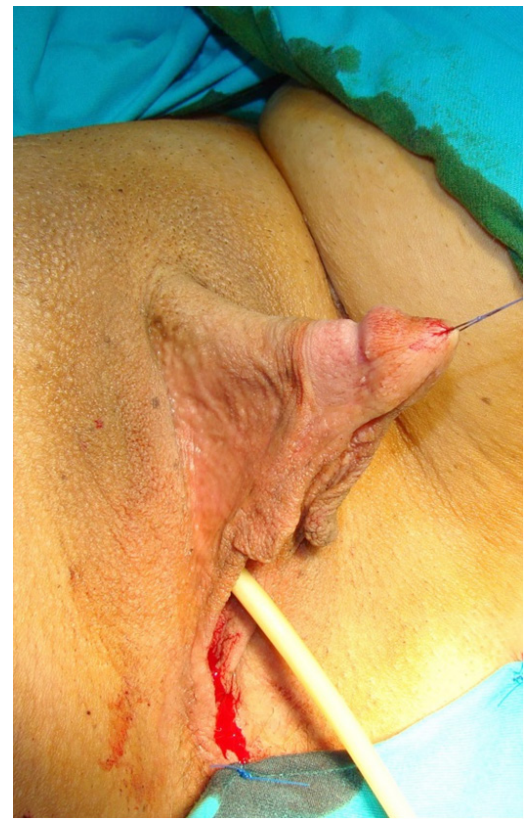

Figure 1. Preoperative appearance. Hypertrophied clitoris under hormonal therapy. Foley catheter inserted into the bladder

introitus, attached ventrally to the clitoral body, and tubularized, thus creating the neophallic urethra. Final urethroplasty is performed by joining the tubularized ring flap and the flap from the anterior vaginal wall in an oblique fashion, while the remaining labial and clitoral skin is used for neophallus shaft reconstruction using multiple Z-plasties to avoid ventral scar contracture ${ }^{[27]}$. Complication rates occurring after ring metoidioplasty vary from $3 \%-5 \%$ for urethral strictures to $10 \%-26 \%$ for urethral fisulae. Ring metoidioplasty is performed as a one-stage procedure, except the scrotoplasty, which is always performed as an additional procedure in one or two stages ${ }^{[25]}$.

Complete metoidioplasty (Belgrade metoidioplasty) is based on the experience in dealing with the most severe forms of hypospadias and disorders of sex development in children ${ }^{[24,28]}$. The latest modification of the original technique involves simultaneous removal of internal female organs, vaginectomy (colpocleisis), complete clitoral lengthening and straightening with the urethroplasty to the tip of the glans, and scrotoplasty with bilateral testicular implants insertion as a one-stage procedure. The current technique relies on the embryological and anatomical homology between the clitoris and penis, confirming the clitoris as a smaller version of the penis with impaired urethral development ${ }^{[2,14]}$ [Figure 1]. The procedure involves laparoscopically-assisted hysterectomy with bilateral salpingo-oophorectomy, if not performed prior to metoidioplasty, and complete vaginal mucosa removal by colpocleisis, with male-like perineoplasty, except for one small portion close to the native urethral meatus. Further, clitoral degloving is performed by a circular incision between the inner and outer layers of the clitoral prepuce downwards to the urethral plate and continued with complete dissection of the superficial and deep portions of the suspensory ligament. Additional straightening and lengthening are obtained by urethral plate dissection to correct ventral chordee [Figure 2]. Urethroplasty is performed using all available hairless skin and/or mucosal grafts over the urethral stent size $12-14 \mathrm{Fr}$ so that standing micturition would be possible, and a suprapubic urinary catheter is introduced to the bladder for urine derivation ${ }^{[5,26,29,30]}$ [Figure $3 \mathrm{~A}$ and B]. Scrotoplasty is performed by joining two labia minora flaps in the midline and inserting two silicone prostheses [Figure 4]. Postoperative care includes administration of broad-spectrum antibiotics and anticholinergic drugs while the suprapubic catheter is in place. Vacuum pump use, in combination with phosphodiesterase Type-5 inhibitors, for a period of six months postoperatively, is advised to prevent retraction of the 


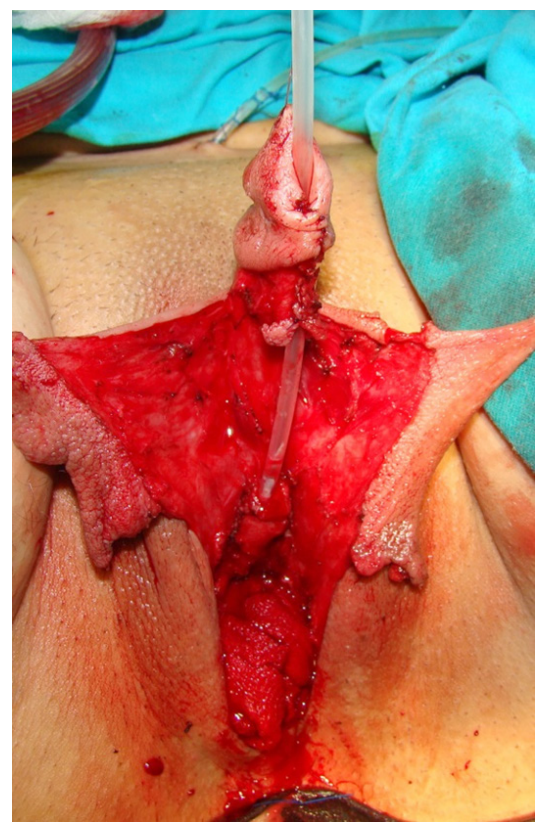

Figure 2. Clitoral lengthening and straightening by urethral plate dissection and suspensory ligaments dissection
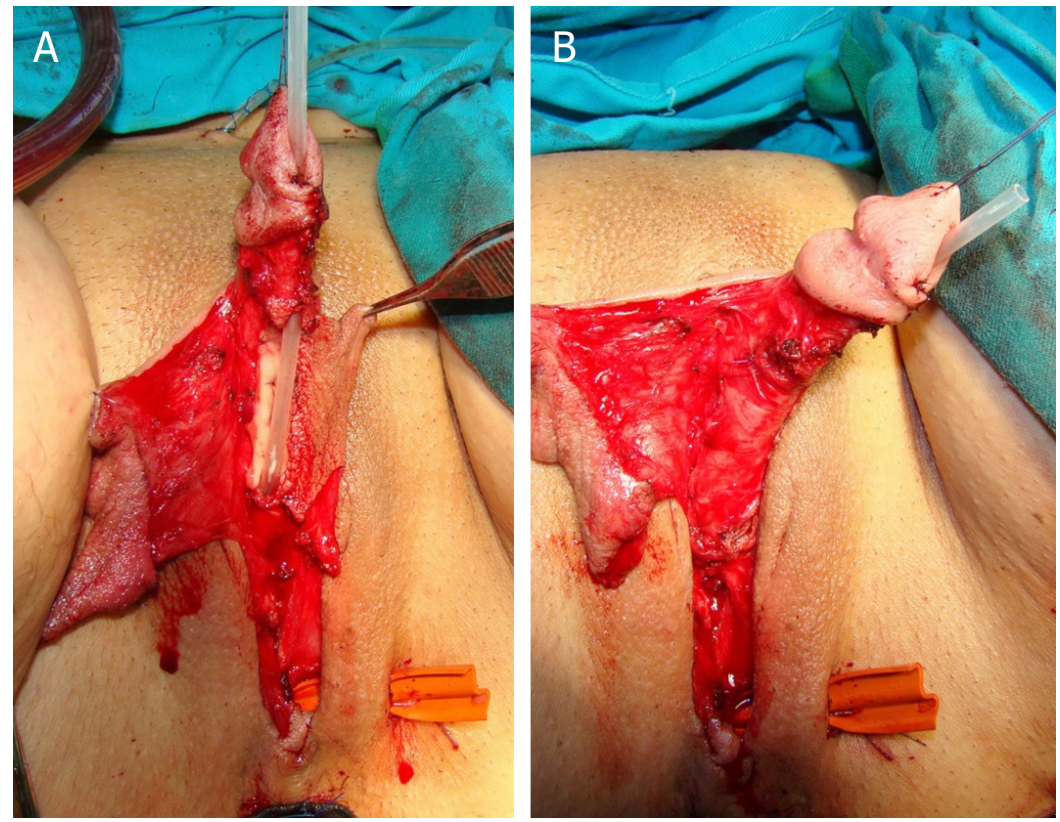

Figure 3. Urethral reconstruction using buccal mucosa graft quilted to the corpora cavernosa and vascularized skin flap originating from the labia minora over the urethral stent (A); All suture lines are covered with vascularized tissue to prevent fistula formation (B)

neophallus ${ }^{[5,31,32]}$. Complications occurring after complete metoidioplasty can be classified as minor or major and vary from $10 \%$ to $37 \%$ depending on different literature data ${ }^{[5,9,33]}$. Minor complications are usually managed conservatively (hematoma, skin infection, urinary tract infection, partial skin necrosis, and dribbling and spraying during voiding). Major complications are usually related to urethroplasty and include either urethral fistulae or stricture, problems with testicular implants (displacement and rejection), and persistent vaginal cavity; these require surgical repair ${ }^{[2,5,26,33,34]}$. In our latest study, we reported overall complications in $46.8 \%$ of our 793 patients. Minor complications occurred in $17.7 \%$ and were solved 


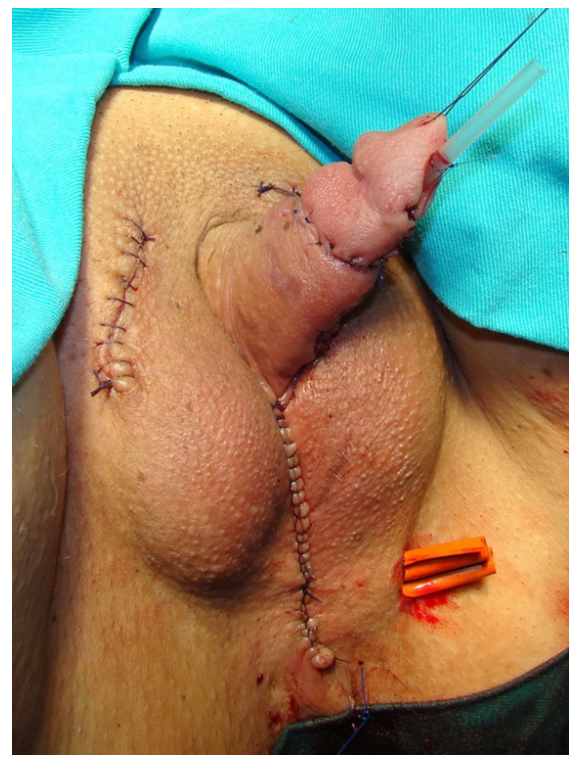

Figure 4. Appearance at the end of surgery. Neophallic skin is reconstructed using available skin from the labia minora and dorsal clitoral skin. Two testicular silicone prostheses are inserted into the scrotum created from the labia majora. Drain is placed in the vaginal vault

Table 1. Postoperative outcomes after metoidioplasty

\begin{tabular}{|c|c|c|c|c|c|c|c|c|c|}
\hline Author/year & $\begin{array}{l}\text { No. of } \\
\text { patients }\end{array}$ & 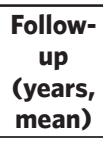 & $\begin{array}{l}\text { Aesthetic } \\
\text { satisfaction } \\
(\%)\end{array}$ & $\begin{array}{l}\text { Voiding } \\
\text { while } \\
\text { standing } \\
\text { (\%) }\end{array}$ & $\begin{array}{c}\text { Erogenous } \\
\text { sensation } \\
(\%)\end{array}$ & $\begin{array}{c}\text { Sexual } \\
\text { intercourse } \\
(\%)\end{array}$ & $\begin{array}{c}\text { Complications } \\
\text { (\%) }\end{array}$ & $\begin{array}{l}\text { Urethral } \\
\text { fistula } \\
\text { (\%) }\end{array}$ & $\begin{array}{c}\text { Urethral } \\
\text { stricture } \\
\text { (\%) }\end{array}$ \\
\hline $\begin{array}{l}\text { Perovic and Djordjevic }{ }^{[24]} \\
2003\end{array}$ & 22 & 3.9 & 77.3 & NA & NA & NA & 22.7 & 13.6 & 9 \\
\hline $\begin{array}{l}\text { Hage and van Turnhout }{ }^{[23]} \\
2006 .\end{array}$ & 70 & 8 & 75.7 & NA & NA & NA & 88.6 & 37.1 & 35.7 \\
\hline $\begin{array}{l}\text { Takamatsu and Harashina }{ }^{[27]} \\
2009\end{array}$ & 43 & 0.6 & 88.4 & 67.4 & 100 & 2.3 & 34.9 & 27.9 & 7 \\
\hline Djordjevic et al. ${ }^{[30]} 2009$ & 38 & 2.2 & 100 & 100 & 100 & 36.8 & 39.5 & 5.3 & 0 \\
\hline Djordjevic and Bizic ${ }^{[29]} 2013$ & 207 & 5.3 & 100 & 91.8 & 100 & NA & 47.8 & 7.7 & 2.9 \\
\hline Vukadinovic et al. ${ }^{[16]} 2014$ & 97 & 2.5 & 95.9 & 100 & 100 & 20.6 & 27.8 & 6.2 & 2.1 \\
\hline Stojanovic et al. ${ }^{[34]} 2017$ & 79 & 3.7 & 96.2 & 100 & 100 & 69.6 & 25.3 & 5.1 & 3.8 \\
\hline Bizic et al. ${ }^{[5]} 2019 \dagger$ & 793 & NA & 94.7 & 100 & 100 & 100 & 46.8 & 8.8 & 1.4 \\
\hline van de Grift et al. ${ }^{[18]} 2019$ & $38^{*}$ & 2.7 & 68 & NA & 36 & 63.5 & NA & NA & NA \\
\hline
\end{tabular}

${ }^{*}$ Twenty-nine patients received phalloplasty and nine patients received metoidioplasty; †Personal experience in review study. NA: not applicable

conservatively and spontaneously, while $29.1 \%$ of our patients required surgical repair because of major complications ${ }^{[5]}$. The majority of patients undergoing metoidioplasty, up to $88 \%$ or more according to recent reports, are satisfied with the appearance of their genitals ${ }^{[5,9,26]}$. Voiding in standing position was possible for the vast majority of patients in recent studies, up to $93.2 \%$ (range 67.4\%-100\%). Recent studies confirmed increased positive association among gender affirmation, body satisfaction, and sexual outcomes after the performed GAS, which was reported for $63.5 \%$ of the patients undergoing metoidioplasty. It may be associated to completely preserved erogenous sensation of the neophallus, which is more prominent. Patients after metoidioplasty report sexual intercourse in a broader sense than just penetration, with increased sexual initiative and pleasure ${ }^{[18]}$. Metoidioplasty, as a one-stage genital gender affirmation surgery, brings about $40 \%$ overall complication rate, the most common complications being related to urethral reconstruction. Urethral fistulae are more common than urethral strictures, and most heal spontaneously ${ }^{[15]}$ [Table 1]. However, between $1 \%$ and $24 \%$ of patients who have undergone metoidioplasty decide to pursue 
some other available phalloplasty procedure in order to obtain the adult-sized neophallus as their final goal $^{[33]}$.

\section{CONCLUSION}

The number of gender affirmation surgeries is increasing worldwide. Specifically, genitourinary surgeries are of vital importance in GAS for transmen. The creation of "ideal" male external genitals is still a great challenge, and no surgical approach can fulfill all the criteria to meet this goal. It is important to offer preand postoperative counseling to patients, to discuss their expectations from the surgery in order to prevent disappointment and improve their subsequent psychosexual functioning.

The neophallus created by metoidioplasty is often shorter when compared with other phalloplasty techniques, and thus inadequate for penetration during sexual intercourse. In some individuals, this may be a limiting factor for upright voiding. On the other hand, individuals who decide to have metoidioplasty as the final option in their transition are more likely to have a single-stage procedure, to keep erogenous sensation, and to avoid multiple surgeries and complications.

In a sense, the majority of metoidioplasty patients get what is considered "ideal" male genitalia in a onestage and time-saving procedure with reduced overall treatment costs and low postoperative complication rate.

\section{DECLARATIONS}

\section{Authors' contributions}

Made substantial contribution to conception and design of the study: Bizic M, Djordjevic $\mathrm{M}$

Performed data analysis and interpretation: Stojanovic B, Bordas N

Performed data acquisition and provided technical support: Stojanovic B, Bencic M

Performed supervision and had responsibility for the organization and course of the project and the manuscript preparation: Bizic M, Djordjevic M

Performed writing of the manuscript: Bizic M, Bordas N, Bencic M

Performed critical review of the manuscript: Djordjevic $M$

\section{Availability of data and materials}

Not applicable.

\section{Financial support and sponsorship}

This study is supported by Ministry of Education, Science and Technological Development, Republic of Serbia (175048).

\section{Conflicts of interest}

All authors declared that there are no conflicts of interest.

\section{Ethical approval and consent to participate}

The study was approved by Institutional Review Board (No. 2-1-1/2020) and an informed consent to participate is obtaioned from the patients prior the surgery.

\section{Consent for publication}

A written informed consent for publication is obtained from patients.

\section{Copyright}

(c) The Author(s) 2020. 


\section{REFERENCES}

1. Coleman E, Bockting W, Botzer M, Cohen-Kettenis P, DeCuypere G, et al. Standards of Care for the health of transsexual, transgender and gender non-conforming people. 7th ed. Int J Transgenderism 2012;13:165-232.

2. Djordjevic ML. Novel surgical techniques in female to male gender confirming surgery. Transl Androl Urol 2018;7:628-38.

3. Zucker KJ. Epidemiology of gender dysphoria and transgender identity. Sex Health 2017;14:404-11.

4. American Psychiatric Association. Diagnostic and statistical manual of mental disorders. 5th ed. Arlington: VA American Psychiatric Association; 2013. pp. 451-9.

5. Bizic MR, Stojanovic B, Joksic I, Djordjevic ML. Metoidioplasty. Urol Clin North Am 2019;46:555-66.

6. Morrison SD, Chen ML, Crane CN. An overview of female-to-male gender-confirming surgery. Nat Rev Urol 2017;14:486-500.

7. Hage JJ, Bout CA, Bloem JJ, Megens JA. Phalloplasty in female-to-male transsexuals: what do our patients ask for? Ann Plast Surg 1993;30:323-6.

8. Lee WG, Christopher N, Ralph DJ. Penile reconstruction and the role of surgery in gender dysphoria. Eur Urol Focus 2019;5:337-9.

9. Frey JD, Poudrier G, Chiodo MV, Hazen A. A systematic review of metoidioplasty and radial forearm flap phalloplasty in female-to-male transgender genital reconstruction: is the "ideal" neophallus an achievable goal? Plast Reconstr Surg Glob Open 2016;4:e1131.

10. Hage JJ. Metaidoioplasty: an alternative phalloplasty technique in transsexuals. Plast Reconstr Surg 1996;97:161-7.

11. Laub DR, Eicher W, Laub DR II, Hentz VR. Penis construction in female-to-male transsexuals. In: Eicher W, Kubli F, Herms V, editors. Plastic surgery in the sexually handicapped. Berlin: Springer; 1989. pp. 113-28.

12. Djordjevic ML, Stanojevic D, Bizic M, Kojovic V, Majstorovic M, et al. Metoidioplasty as a single stage sex reassignment surgery in female transsexuals: belgrade experience. J Sex Med 2009;6:1306-13.

13. Mazloomdoost D, Pauls RN. A comprehensive review of the clitoris and its role in female sexual function. Sex Med Rev 2015;3:245-63.

14. Stojanovic B, Djordjevic ML. Anatomy of the clitoris and its impact on neophalloplasty (metoidioplasty) in female transgenders. Clin Anat 2015;28:368-75.

15. Hadj-Moussa M, Agarwal S, Ohl DA, Kuzon WM Jr. Masculinizing genital gender confirmation surgery. Sex Med Rev 2019;7:141-55.

16. Vukadinovic V, Stojanovic B, Majstorovic M, Milosevic A. The role of clitoral anatomy in female to male sex reassignment surgery. ScientificWorldJournal 2014;2014:437378.

17. Clerico C, Lari A, Mojallal A, Boucher F. Anatomy and aesthetics of the labia minora: the ideal vulva? Aesthetic Plast Surg 2017;41:714-9.

18. van de Grift TC, Pigot GLS, Kreukels BPC, Bouman MB, Mullender MG. Transmen's experienced sexuality and genital gender-affirming surgery: findings from a clinical follow-up study. J Sex Marital Ther 2019;45:201-5.

19. Durfee R, Rowland W. Penile substitution with clitoral enlargement and urethral transfer. In: Laub DR, Gandy P, editors. Proceedings of the second interdisciplinary symposium on gender dysphoria syndrome. Palo Alto: Stanford University Press; 1973. pp. 181-3.

20. Lebovic GS, Laub DR. Metoidioplasty. In: Ehrlich RM, Alter GJ, editors. Reconstructive and plastic surgery of the external genitalia: adult and pediatric. Philadelphia: WB Saunders Co.; 1999. pp. 355-60.

21. Bouman FG. The first step in phalloplasty in female transsexuals. Plast Reconstr Surg 1987;79:662-4.

22. Gilbert DA, Winslow BH, Gilbert DM, Jordan GH, Horton CE. Transsexual surgery in the genetic female. Clin Plast Surg 1988;15:471-87.

23. Hage JJ, van Turnhout AA. Long-term outcome of metaidoioplasty in 70 female-to-male transsexuals. Ann Plast Surg 2006;57:312-6.

24. Perovic SV, Djordjevic ML. Metoidioplasty: a variant of phalloplasty in female transsexuals. BJU Int 2003;92:981-5.

25. Bowers ML, Stojanovic B, Bizic M. Female-to-male gender affirmation metoidioplasty. In: Salgado CJ, Monstrey SJ, Djordjevic ML, editors. Gender affirmation: medical and surgical perspectives. New York: Thieme Medical Publishers Inc; 2017. pp. 109-18.

26. Djordjevic ML, Stojanovic B, Bizic M. Metoidioplasty: techniques and outcomes. Transl Androl Urol 2019;8:248-53.

27. Takamatsu A, Harashina T. Labial ring flap: a new flap for metaidoioplasty in female-to-male transsexuals. J Plast Reconstr Aesthet Surg 2009;62:318-25.

28. Djordjevic ML, Majstorovic M, Stanojevic D, Bizic M, Kojovic V, et al. Combined buccal mucosa graft and dorsal penile skin flap for repair of severe hypospadias. Urology 2008;71:821-5.

29. Djordjevic ML, Bizic MR. Comparison of two different methods for urethral lengthening in female to male (metoidioplasty) surgery. J Sex Med 2013;10:1431-8.

30. Djordjevic ML, Bizic M, Stanojevic D, Bumbasirevic M, Kojovic V, et al. Urethral lengthening in metoidioplasty (female-to-male sex reassignment surgery) by combined buccal mucosa graft and labia minora flap. Urology 2009;74:349-53.

31. Djordjevic ML, Bizic MR, Stanojevic D. Phalloplasty in female-to-male transsexuals. In: Djordjevic M, Santucci R, editors. Penile reconstructive surgery. Saarbrucken: LAP Lambert Academic Publishing; 2012. pp. 279-304.

32. Bizic MR, Stojanovic B, Djordjevic ML. Genital reconstruction for the transgendered individual. J Pediatr Urol 2017;13:446-52.

33. Nikolavsky D, Hughes M, Zhao LC. Urologic complications after phalloplasty or metoidioplasty. Clin Plast Surg 2018;45:425-35.

34. Stojanovic B, Bizic M, Bencic M, Kojovic V, Majstorovic M, et al. One-stage gender-confirmation surgery as a viable surgical procedure for female-to-male transsexuals. J Sex Med 2017;14:741-6. 